\title{
特集＼cjkstart腎機能障害者に対するリハビリテーション治療
}

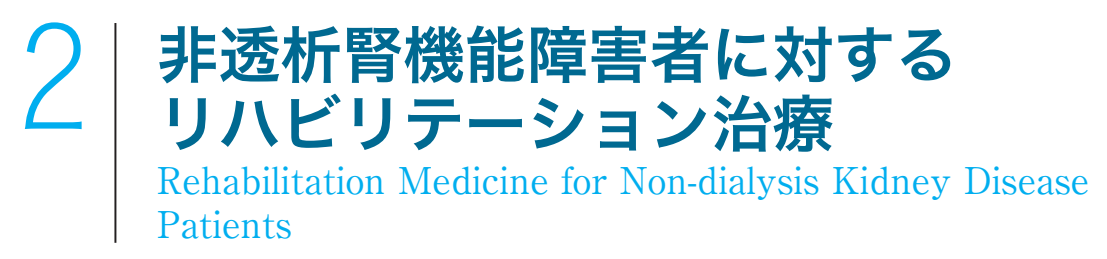

高橋麻子*1, 2 伊藤 修*1,2

Asako Takahashi Osamu Ito

Key words : 糸球体腎炎 /ネフローゼ症候群／保存期慢性腎臟病／運動療法

慢性透析患者数が増加している中, 透析に至っていない腎機能障害患者の治療においては, その進行を防ぎ, 透析導入を遅らせる有効な対策を立てることが重要である. 近年, 腎障害 患者における適度な運動は腎機能には悪影響を及ぼさずに運動耐容能, 筋力の向上および健 康関連 QOL の改善をもたらすことが報告されるようになり, また, 運動療法は腎機能維持 のための介入手段の 1 つとしても期待されるようになった.この流れを受け, 2011 年に日 本腎臓リハビリテーション学会が設立され，2018 年には『腎臓リハビリテーションガイドラ イン』が作成された。本稿では, 非透析腎機能障害患者（糸球体腎炎, ネフローゼ症候群, 保存期慢性腎藏病患者）への運動療法の内容や効果について, ガイドラインをもとに概説す る.

\section{糸球体腎炎，ネフローゼ症候群 患者に対する運動療法}

糸球体腎炎やネフローゼ症候群を含む慢性糸球 体腎炎が原因で透析導入に至る患者は減少傾向に あるが，2015 年に IgA 腎症，一次性ネフローゼ症 候群, 一次性膜性増殖性系球体腎炎などが指定難 病となり, 希少疾患としての重要性は増している1). 糸球体腎炎安定期やネフローゼ症候群寛解期など に運動療法を取り入れることで ADL の改善が期

*1 東北医科薬科大学医学部リハビリテーション学 *2 東北医科薬科大学病院リハビリテーション科

【連絡先】 $\bar{T} 983-8512$ 宮城県仙台市宮城野区福室 1-12-1 東北医科薬科大学病院リハビリテーショ ン科 高橋麻子

E-mail : namaia@tohoku-mpu.ac.jp DOI : 10.2490/jjrmc.57.208

\section{(c) BY-NC-ND}

待されるところであるが, 今まで成人および小児の 糸球体腎炎患者やネフローゼ症候群患者に対する 運動療法については, 主に安静や運動制限を強い てきた経緯もあり，いまだ体系的なエビデンスがな いのが現状である.

慢性系球体腎炎患者に対して運動療法が予後を 増悪させるというエビデンスはなく, また, 安静や 運動制限が予後を改善するというエビデンスも明 らかではない，よって，腎臓リハビリテーションガ イドラインでは, 糸球体腎炎患者に一律に運動制 限を行わないことを提案している1)。ただし, 安定 期において許容される運動負荷レベルや運動処方 についても明らかになっていない. また, 寛解期の ネフローゼ症候群患者においても運動制限を支持 するエビデンスはないため, 腎臓リハビリテーショ ンガイドラインでは, 過度な安静や運動制限を行わ ない，という提案にとどまっている1). 
今のところ, 慢性の糸球体腎炎や寛解期のネフ ローゼ症候群に対して数少ない報告があるのみで あり，尿蛋白が高度なケースや腎機能が短期間で 急激に低下するケースについては運動療法に関す るエビデンスはない. 個々の症例について病期や 臨床症状, 身体能力などを十分に評価したうえで, それぞれ適応や程度を判断する必要がある。

\section{保存期 CKD 患者に対する 運動療法}

\section{1. 保存期 CKD 患者の身体機能と 運動療法の効果}

慢性腎臟病（chronic kidney disease：CKD）患 者では, 体液異常・貧血・血行動態異常などの合 併によって心機能が低下している，また，炎症性 サイトカインの増加, 代謝性アシドーシス, 活性型 ビタミン D の低下, 筋内レニン-アンジオテンシン 系の活性化, 食欲低下, protein-energy wasting, 性ホルモンや成長ホルモンの変化, インスリン抵抗 性など2)に加え, 運動が腎機能悪化をきたすとの考 え方から安静を強いられてきたことなどで廃用が 進んで扔り，運動耐容能が低下している．CKD 初 期でも, ほとんど自覚症状はないものの早期から身 体能力が低下するといわれている. Roshanravan らの報告によると，ステージ 2〜4の CKD 患者に おいて, 歩行速度や 6 分間歩行距離は健常人の 7 割程度に低下, Timed Up and Go（TUG）時間は 4 割程度延長していた ${ }^{3)}$ 。さらに, これらの身体機能 低下は CKD 患者の生命予後に大きく影響してお り, 腎機能や血清バイオマーカーよりも 3 年後の死 亡リスクをより強力に予想できていだ3).

近年のメ夕解析では, 腎障害患者における適度 な運動は腎機能には悪影響を及ぼさずに運動耐容 能, 筋力の向上および健康関連 QOL の改善をもた らすという結果が示されている ${ }^{4,5)}$. 低蛋白食摂取 下であっても蛋白異化を防止するという報告もあ $\eta^{6)}$ ，CKD 患者の活動を過度に制限すべきではな いことも示唆されている. 運動の腎機能への効果 としては, レジスタンス運動による糸球体滤過量 (glomerular filtration rate：GFR) の悪化はなく, 非運動群に比べて有意に改善したことが報告され ている7). 有酸素運動とレジスタンス運動を組み 合わせた運動療法を週 3 回 12 力月継続したとこ ろ, 運動療法群では非介入群に比べて推定 GFR の低下を有意に抑制した ${ }^{8)}$ 。また, 特別な運動療 法でない身体活動を高める歩行のみであっても, CKD 患者の 10 年間の全死亡リスクを $33 \%$, 腎代 替療法移行リスクを $22 \%$ 低下させ, 週あたり運動 実施回数が多いほどそれらのリスクをより低下さ せることが報告されている ${ }^{9)}$. 本邦からも, 有酸素 運動を中心とした 3 カ月間の回復期心臓リハビリ テーションが CKD を有する急性心筋梗塞患者の 推定 GFR を改善させることが報告された ${ }^{10)}$.こ れらのことから, 腎臓リハビリテーションガイドラ インでも，CKD 患者に対して年齢や身体機能を考 慮しながら可能な範囲で運動療法を行うことを提 案する（推奨度 2 , エビデンスレベル C), とされて いる1).

\section{2. 保存期 CKD 患者への 運動療法の内容}

\section{1) 適応と禁忌}

保存期 CKD 患者の運動療法の対象者はあくま で病態の安定した患者である ${ }^{1)}$. 本邦では CKD 患者への運動療法の禁忌や中止基準はないが, $\mathrm{CKD}$ の原因疾患が生活習慣病由来の場合は生活 習慣病に対する運動療法の適応と禁忌を（表 1) ${ }^{1)}$, 心血管疾患を合併した CKD 患者に対しては運動 療法開始の際のフローチャートを参考にするとよ い $(\text { 図 1 })^{1)}$ 。さらに, CKD 患者はさまざまなリス クを伴っているため, 運動療法を行う際にはリスク 管理も重要である (表 2) ${ }^{1)}$. 
表 1 生活習慣病に対する運動療法の適応と禁忌（文献 1 p33 より引用改変）

\begin{tabular}{|c|c|c|c|}
\hline 疾患 & 適応 & 条件付適応 & 禁忌 \\
\hline 高血圧 & $140 \sim 159 / 90 \sim 94 \mathrm{mmHg}$ & $\begin{array}{l}\text { 160 179/95 99 mmHg } \\
\text { または治療中かつ禁忌の值でない } \\
\text { 男性 } 40 \text { 歳, 女性 } 50 \text { 歳以上はでき } \\
\text { るだけ運動負荷試験を行う } \\
\text { 運動負荷試験ができない場合は } \\
\text { ウォーキング程度の処方とする }\end{array}$ & $\begin{array}{l}\text { 180/100 mmHg 以上 } \\
\text { 胸部X 線写真で CTR : } 55 \% \text { 以上 } \\
\text { 心電図で重症不整脈, 虚血性変 } \\
\text { 化が認められるもの（運動負荷 } \\
\text { 試験で安全性が確認された場合 } \\
\text { は除く） } \\
\text { 眼底で } \| \mathrm{b} \text { 以上の高血圧性変化 } \\
\text { がある } \\
\text { 尿蛋白：100 } \mathrm{mg} / \mathrm{dL} \text { 以上 }\end{array}$ \\
\hline 糖尿病 & 空腹時血糖 : 110～139 mg/dL & $\begin{array}{l}\text { 空腹時血糖：140～} 249 \mathrm{mg} / \mathrm{dL} \\
\text { または治療中かつ禁忌の值でない } \\
\text { 男性 } 40 \text { 歳, 女性 } 50 \text { 歳以上はでき } \\
\text { るだけ運動負荷試験を行う } \\
\text { 運動負荷試験ができない場合は } \\
\text { ウォーキング程度の処方とする }\end{array}$ & $\begin{array}{l}\text { 空腹時血糖： } 250 \mathrm{mg} / \mathrm{dL} \text { 以上 } \\
\text { 尿ケトン体 }(+) \\
\text { 糖尿病性網膜症 }(+)\end{array}$ \\
\hline 脂質異常症 & $\begin{array}{l}\mathrm{TC}: 220 \sim 249 \mathrm{mg} / \mathrm{dL} \\
\text { または } \\
\text { TG : 150〜299 mg/dL }\end{array}$ & $\begin{array}{l}\text { TC : } 250 \mathrm{mg} / \mathrm{dL} \text { 以上または TG : } \\
300 \mathrm{mg} / \mathrm{dL}, \text { または治療中 } \\
\text { 男性 } 40 \text { 歳, 女性 } 50 \text { 歳以上はでき } \\
\text { るだけ運動負荷試験を行う } \\
\text { 運動負荷試験ができない場合は } \\
\text { ウォーキング程度の処方とする }\end{array}$ & \\
\hline 肥満 & BMI : $24.0 \sim 29.9$ & $\begin{array}{l}\text { BMI：24.0 29.9 かつ下肢の関節障 } \\
\text { 害整形外科的精査と運動制限 }\end{array}$ & $\mathrm{BMI}: 30.0$ 以上 \\
\hline
\end{tabular}

TC : 総コレステロール, TG : 中性脂肪, BMl : Body Mass Index〔体重 $(\mathrm{kg}) /$ 身長 $(\mathrm{m})^{2}$ )
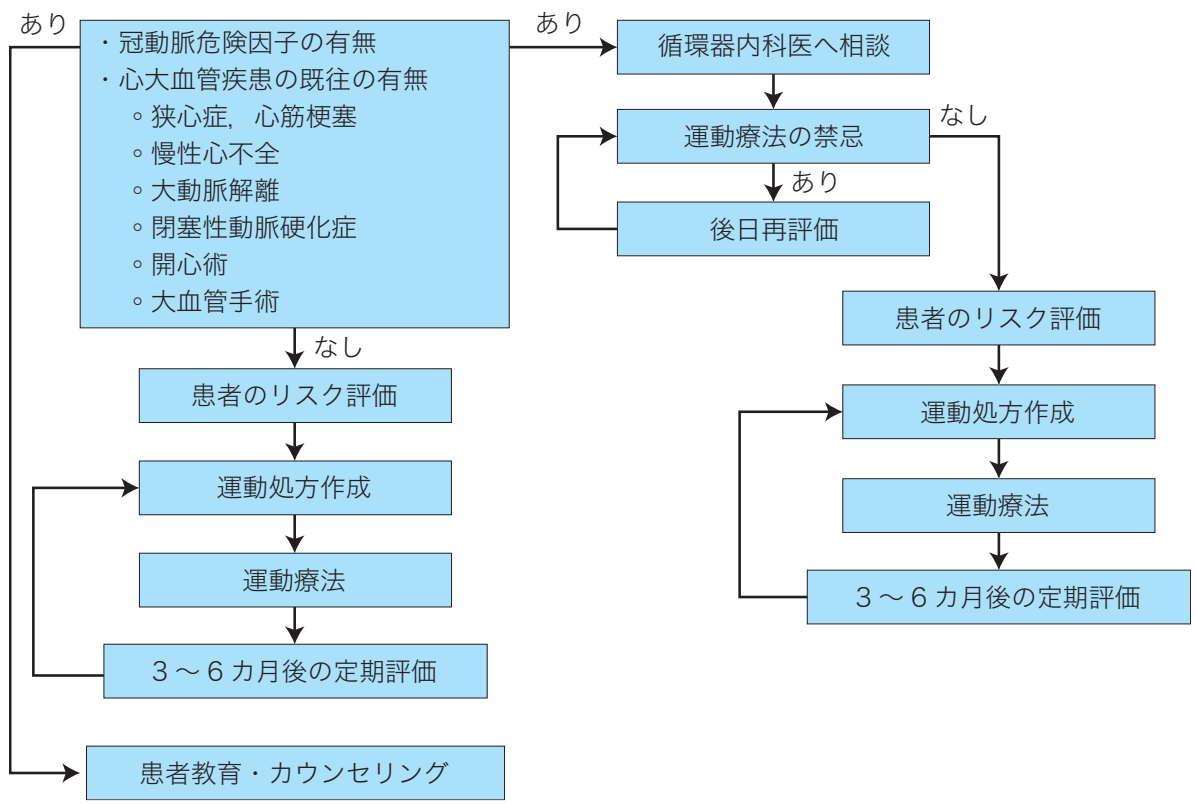

図 1 保存期 CKD 患者に対する運動療法のフローチャート（文献 1 p34 より引用改変） 


\section{表 2 保存期 CKD 患者の運動療法施行時のリスク管理（文献 1 p 34 より引用改变）}

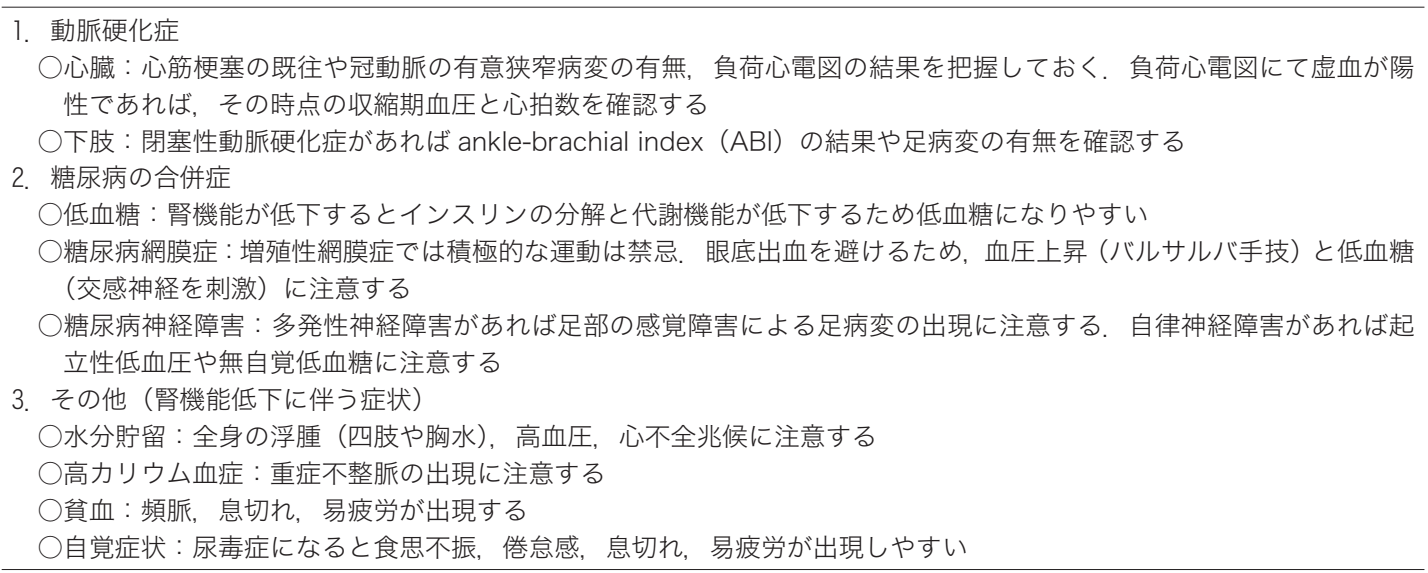

\section{2）有酸素運動とレジスタンストレーニング}

腎血流量は腎機能の中で運動により最も顕著な 影響を受け，激しい運動時には 50〜 75\%も低下す ることが知られている．短期的に運動を行うと尿 蛋白排泄量が増加し, 腎血流量や GFR が減少す ることから ${ }^{11,12)}$, 高強度の運動を行うと腎機能障 害や腎病変が増悪する危険があるとされている. また，CKD 患者では心血管疾患を合併しているこ とが多いこともあり，有酸素運動についてはできる 限り心肺運動負荷試験（Cardiopulmonary Exercise Test : CPX) を行い, 嫌気性代謝閾值 (anaerobic threshold：AT）を評価したうえでATレべ ルでの運動を行うことが望ましい. CPXが実施で きない場合は自覚的運動強度やモニター心電図な どを用いてモニタリングしながら行うようにする. レジスタンストレーニングについても同様であり, 可能な限り最大筋力の評価をしたうえで行うか, 評価困難な場合は自覚的運動強度などを利用す る ${ }^{13)}$ ，有酸素運動，レジスタンストレーニングい ずれにおいても『心血管疾患におけるリハビリテー

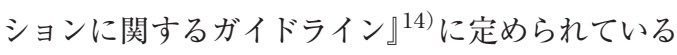
適応, 禁忌, 中止基準が推奨される.

\section{3）運動処方}

米国スポーツ医学会から発表された「運動負荷
試験と運動処方のガイドライン」 ${ }^{15)}$ では, CKD 患 者の運動処方は, 初期の運動強度を軽度強度（酸 素摂取予備能の $40 \%$ 未満）から中等度強度（酸素 摂取予備能の 40～60\%）にし，患者の運動耐容能 に基づいて時間をかけて徐々に進行させていくと 述べられている。 また，レジスタンストレーニング は, 安定した CKD 患者の総体的な健康のために 重要であるとも述べられている。本邦では, 保存 期 CKD 患者に対する確立された運動処方はなく， 腎臓リハビリテーションガイドラインではこの勧告 を参考にした監視下運動療法と非監視下運動療法 が提案されている $(\text { 表 3，4 })^{1}$ ）。だし, 現時点で CKD のステージごとに分けて検討した報告はない ため, 病期によって運動療法の内容を分けていな い.

\section{おわりに}

糸球体腎炎やネフローゼ症候群患者に対する運 動療法についてはエビデンスがほとんどない. 同 様に, 保存期 CKD 患者における運動の効果を明 らかにした成績も少なく, 腎障害患者に対する具 体的な運動強度や運動時間が科学的根拠に基づい て明らかにされているわけではない. しかし, 高齢 化に伴い今後も慢性透析患者数が増加すると予想 
表 3 保存期 CKD 患者に対する監視下運動療法（文献 1 を参考に作成)

\begin{tabular}{|c|c|c|}
\hline & 有酸素運動 & レジスタンストレーニング \\
\hline 頻度 & 週 3〜 5 回 & 週 2～3 回 \\
\hline \multirow[t]{2}{*}{ 強度 } & $\begin{array}{l}\text { 中等度レベル } \\
\text { \% HRmax : 50〜 70\% } \\
\text { カルボーネン法 : 40 60\% } \\
\text { Borg 指数 : 11〜 13 }\end{array}$ & $\begin{array}{l}\text { 中等度レベル } \\
\text { 40〜60\% 1RM }\end{array}$ \\
\hline & \multicolumn{2}{|c|}{$\begin{array}{l}\text { 運動習慣のない者や低体力者は軽負荷の運動から開始し, 疲労や痛みがなけれぱ徐々に強み. } \\
\text { 度を上げる. }\end{array}$} \\
\hline 持続時間 & $\begin{array}{l}\text { ·持続的な運動を } 20 \sim 60 \text { 分/日 } \\
\text { ·運動習慣のない者や低体力者は } 5 \text { ～10 分 } \\
\text { 程度から開始し, 疲労がなければ徐々に } \\
\text { 延長する }\end{array}$ & 1 セット 10〜15 回を 1〜数セット \\
\hline 種類 & $\begin{array}{l}\text { ウォーキング, 自転車, 水中運動, 水泳, } \\
\text { レッドミル, 自転車エルゴメーター }\end{array}$ & $\begin{array}{l}\text { マシーン, 重鍾バンド, 自重 (スクワットや } \\
\text { カーフレイズ), トレーニング, チューブ }\end{array}$ \\
\hline
\end{tabular}

IRM : 1 repetition maximum（最大 1 回反復重量）

表 4 保存期 CKD 患者に対する非監視下運動療法（文献 1 を参考に作成）

\begin{tabular}{|c|c|c|}
\hline & 有酸素運動 & レジスタンストレーニング \\
\hline 頻度 & \multirow{4}{*}{$\begin{array}{l}\text { 歩数計を使用し定量化する. 運動療法開始前 } \\
\text { にベースラインを評価し, 目標歩数を設定す } \\
\text { る. まず } 1 \text { 日 } 500 〜 1,000 \text { 歩の増加を目標とし, } \\
\text { 最終的には } 1 \text { 日 } 6,000 〜 10,000 \text { 歩を目標とする. }\end{array}$} & 週 2～3 回 \\
\hline 強度 & & 低～中等度 \\
\hline 持続時間 & & 10〜20 回を 1〜3 セット \\
\hline 種類 & & トレーニングチューブや自重負荷 \\
\hline
\end{tabular}

される中, 運動療法は CKD 患者の運動耐容能, 筋 力の向上および健康関連 QOL の改善だけでなく, 腎機能維持のための介入手段の 1 つとしても期待 されている. 今後さらなるエビデンスの構築が期 待される.

\section{文 献}

1）日本腎臓リハビリテーション学会 編：腎蔵リハビリ テーションガイドライン. 南江堂, 東京, 2018

2) Fahal IH : Uraemic sarcopenia : aetiology and implications. Nephrol Dial Transplant $2013 ; 29$ : 16551665

3) Roshanravan B, Robinson-Cohen C, Patel KV, Ayers E, Littman AJ, de Boer IH, Ikizler TA, Himmelfarb J, Katzel LI, Kestenbaum B, Seliger S : Association between physical performance and all-cause mortality in CKD. J Am Soc Nephrol $2013 ; 24$ : 822-830

4) Johansen $K$, Painter $P$ : Exercise in individuals with CKD. Am J Kidney Dis $2012 ; 59:$ 126-134

5) Heiwa $\mathrm{S}$, Jacobson $\mathrm{SH}$ : Exercise training in adults with CKD : a systematic review and meta-analysis.
Am J Kidney Dis $2014 ; 64: 383-393$

6) Castaneda C, Gordon PL, Parker RC, Uhlin KL, Roubenoff R, Levey AS : Resistance training to reduce the malnutrition-inflammation complex syndrome of chronic kidney disease. Am J Kidney Dis $2004 ; 43: 607-616$

7) Castanede C, Gordon PL, Uhlin KL, Levey AS, Kehayias JJ, Dwyer JT, Fielding RA, Roubenoff R, Singh MF : Resistance training to counteract the catabolism of a low-protein diet in patients with chronic renal insufficiency. A randomized, controlled trial. Ann Intern Med $2001 ; 135$ : 965-976

8) Greenwood SA, Koufaki P, Mercer TH, MacLaughlin HL, Rush R, Lindup H, O’Connor E, Jones C, Hendry BM, Macdougall IC, Cairns HS : Effect of exercise training on estimated GFR, vascular health, and cardiorespiratory fitness in patients with CKD : a pilot randomized controlled trial. Am J Kidney Dis $2015 ; 65: 425-434$

9) Chen IR, Wang SM, Liang CC, Kuo HL, Chang CT, Liu JH, Lin HH, Wang IK, Yang YF, Chou CY, Huang CC: Association of walking with survival and RRT among patients with CKD stages 3-5. Clin J Am Soc Nephrol $2014 ; 9$ : 1183-1189

10) Takaya Y, Kumasaka R, Arakawa T, Ohara T, 
Nakanishi M, Noguchi T, Yanase M, Takaki H, Kawano Y, Goto Y : Impact of cardiac rehabilitation on renal function in patients with and without chronic kidney disease after acute myocardial infarction. Circ J $2014 ; 78: 377-384$

11) Poortmans JR, Mathieu N, de Plaen $P$ : Influence of running different distances on renal glomerular and tubular impairment in humans. Eur J Appl Physiol Occup Physiol $1996 ; 72: 522-527$

12) Clorius JH, Mandelbaum A, Hupp T, Reinbold F, Zuna I, Denk S, Fellhauer C, van Kaick G : Exercise activates renal dysfunction in hypertension. Am J
Hypertens $1996 ; 9: 653-661$

13) 重田暁：慢性腎蔵病 (chronic kidney disease： CKD) に対する運動療法の最前線. 理学療法学 $2017 ; 44: 158-165$

14) 日本循環器学会 : 心血管疾患におけるリハビリテー ションに関するガイドライン (2012 年改訂版), 2015 年 1 月 4 日更新版, Available from URL : http:// www.j-circ.or.jp/guideline/pdf/JCS2012_nohara_h. pdf

15）日本体力医学会体力科学編集委員会 監訳 : 運動処 方の指針一運動負荷試験と運動プログラム一原書第 8 版. 南江堂, 東京, 2011 